\title{
PENGUATAN PETANI MILENIAL DALAM INISIASI BUDIDAYA CABAI DI LUAR MUSIM BERBASIS TEKNOLOGI TETES AIR DI PLERET, BANTUL, DIY
}

\author{
A Wibowo Nugroho Jati ${ }^{1}$, Stefanus Nindito ${ }^{2}$, Suryo Adi Pramono ${ }^{3}$, Yustina Niken Sharaningtyas ${ }^{4}$, Benedita Dea Puspita ${ }^{5}$ \\ Universitas Atma Jaya Yogyakarta, Jalan Babarsari No. 44 Yogyakarta \\ Email: niken.sharaningtyas@uajy.ac.id
}

Received: December 28, 2021 ; Revised: -; Accepted for Publication January 3, 2022; Published: January 5, 2022

\begin{abstract}
Dunia pertanian langka petani muda langka. Di Daerah Istimewa Yogyakarta (DIY) usia petani umumnya di atas 40 tahun. Sebab itu BPP Pleret mencoba untuk membangun petani muda dalam dua tahun terakhir: Kelompok Tani Perwira. Oleh karena mereka bukanlah petani yang biasa terjuna ke sawah maka teknologi diperlukan untuk memacu mereka. Koordinator BPP Pleret berinisiatif untuk mendorong mereka dalam budidaya cabai di luar musim dengan menggunakan teknologi tertentu yang memudahkan mereka bertani. Untuk mendukung itu, Tim Pengabdian pada Masyarakat (PPM) Universitas Atma Jaya Yogyakarta (UAJY) mendukung upaya itu dengan menawarkan metode teknologi tetes air. Tujuan PPM ini adalah mendukung dan mendampingi Tani Perwira menerapkan sistem tetes dan membuat pupuk organik cair. Hamparan bibit cabai yang disemai di dalam greenhouse kemudian ditanam di lahan tanah bermulsa dengan dukungan teknologi tetes. Traktor disediakan untuk mengolah tanah. Tandon air dirancang khusus untuk irigasi tanaman melalui paralon dan selang tetes. Para petani muda (milenial) tinggal memantau tanaman di lahan dan mengatur keran air ketika menyirami tanaman cabai sampai nanti panen. Selama budidaya berlangsung, penyuluh lapangan BPP Pleret mendampingi para petani muda bekerjasama dengan Tim PPM UAJY sesuai dengan tata-kala. Hasilnya, Perwira Tani antusias bertani. Kesimpulan: teknologi mampu mendorong petani muda bersemangat dalam budidaya pertanian.
\end{abstract}

Keywords - Teknologi tetes, pupuk organik cair, petani milenial, pendampingan

\section{PENDAHULUAN}

Titik tolak pengabdian ini berdasarkan hasil penelitian pendahuluan tentang pertanian organik di Yogyakarta. Awalnya berpangkal dari berbagai kelompok masyarakat sipil dan gerakan sosial yang mempraktekkan metode pertanian alternatif yang berbeda dari pertanian konvensional. Seiring waktu, pertanian organik di Indonesia terus berkembang hingga menjadi cara bertani yang sekarang didukung pemerintah dan menjadi obyek kebijakan pertanian dengan tujuan industrialisasi skala besar.

Dalam perkembangan ini, aspek gerakan sosial dari pertanian organik menjadi surut dibandingkan perkembangan aspek agro-ekonomi. Oleh karena itu, penelitian ini bertujuan untuk melakukan peninjauan kembali ke tiga kelompok perintis gerakan organik di Yogyakarta, yang beberapa di antaranya dulu pernah dikaji oleh salah satu peneliti [1] Ketiga kelompok itu adalah Sekretariat Nelayan dan Petani Hari Pangan Sedunia (SPTN-HPS) di Ganjuran, kelompok petani aktivis di Keceme, Sleman, serta Koperasi Sahani. Pengumpulan data menggunakan pendekatan kualitatifeksploratif yang berpijak pada wawancara mendalam dan terstruktur dengan berbagai informan kunci yang diseleksi memakai purposive sampling berdasarkan peran mereka dalam organisasi serta melalui referensi lanjut dari informan. Selain itu tim peneliti juga melakukan observasi terhadap lokasi dan kegiatan kelompok, serta pengumpulan data sekunder kelompok, sebagai triangulasi dari data naratif wawancara. Temuan penelitian menunjukkan bahwa ketiga organisasi perintis pertanian organik bermula pada upaya mengembangkan metode pertanian ini sebagai reaksi terhadap dominasi pertanian konvensional berbasis Revolusi Hijau, sebagai upaya pemberdayaan kemandirian kelompok petani vis-à-vis struktur pertanian konvensional, serta sebagai upaya menanggulangi kerugian ekologis dan hayati dari pertanian konvensional.

Ketiga organisasi pada awalnya juga memakai pendekatan yang mirip, yaitu dengan upaya pelatihan metode pertanian organik serta pendampingan kelompok petani. Namun, terjadi pergeseran fokus kegiatan pada dua organisasi, yaitu SPTN-HPS dan Sahani, yang sekarang beralih pada pengembangan usaha pemasaran produk organik. Faktor utama penyebab pergeseran ini adalah berhentinya atau berubahnya pola pendanaan dari luar organisasi, yang cenderung bergantung pada donor, baik domestik maupun asing. Selain itu, kedua organisasi ini juga berhadapan pada pertanian organik yang sudah memasuki fase sertifikasi pada dekade 2000an (David dan Ardiansyah 2016), yang berakibat makin pentingnya aspek ekonomi dari pertanian organik. Sebaliknya, para petani aktivis di Keceme tetap bertahan dengan metode pertanian mereka yang holistik dan berskala kecil dengan penekanan utama pada subsistensi dahulu. Sifat informal dan cair dari kelompok petani aktivis ini memungkinkan mereka untuk lebih tahan terhadap perubahan pendanaan namun berakibat bahwa gerakan mereka cenderung berskala kecil dan lokal [2]

Dasar pemikiran lain pelaksanaan pengabdian dengan juga terkait dengan keterkaitan pengembangan kelembagaan pertanian organik yang sudah berhasil di Kecamatan Pajangan kabupaten Bantul. Keberhasilan tersebut tidak lepas dengan masuknya Program Pengabdian pada Masyarakat Universitas Atma Jaya Yogyakarta (PPM UAJY) dan Pendamping Pertanian Lapangan (PPL) setempat, yaitu Pak Sugeng Diono dan Ibu Budi yang sebelumnya berhasil mendampingi Petani Pajangan dinilai cukup berhasil di wilayah Pajangan Bantul yang kemudian pindah ke Pleret. Berkaitan dengan kepindahan PPL dengan berkolaborasi tim PPM UAJY tersebut besar harapan pengembangan pertanian akan terus berlanjut di Pleret wilayah baru tersebut. 
Selain itu pelaksanaan PPM UAJY tersebut terkait juga dengan program Merdeka Belajar Kampus Merdeka (MBKM) dengan melibatkam mahasiswa sehingga sekaligus dapat menerapkan displin ilmunya untuk dapat mendukung pelaksanaan PPM.

Pleret berarti daerah bertopografi miring di sisi sungai. Dulu kecamatan ini pernah menjadi lokasi Kerajaan Mataram pada abad ke 17 [3]. Namun karena perkembangan keadaan geografis, Pleret akhirnya terkategori sebagai daerah kering karena setelah gempa pada tahun 2006 banyak selokan pengairan yang rusak parah. Daerah sungai juga banyak diambil pasirnya untuk bahan bangunan sehingga banyak mata air yang mati. Ketika kemarau kekurangan air, tetapi ketika hujan tergenang air sehingga banyak tanaman mati. Daerah kering terutama di daerah Desa Wonolelo sisi timur yang berada di bawah daerah Cino Mati. Di dalam konteks lahan seperti itu, para petani banyak dirugikan.

Berkaitan dengan pelaksanaan pengabdian untuk membangun optimisme para petani, BPP Pleret menggandeng Kelompok "Tani Perwira" yang telah setahun berjalan untuk membuat contoh budidaya pertanian"organik" terpadu di lahan BPP Pleret yang tahan terhadap persoalan air di musim kemarau dan penghujan dengan adopsi teknik pertanian tertentu. Kelompok yang memiliki anggota 20 orang yang berada di sejumlah pedukuhan dengan minat bertani yang beragam ini dikoordinir oleh Mbak Puspita. Mereka memiliki beberapa motor penggerak dan pemikir, di samping petani pelopor yang kreatif: Mas Suryono. Keduanya dan Mas Endri menjadi kekuatan inti dari beberapa orang penggerak di dalamnya. BPP menggandeng kelompok ini, bahkan membidani pembentukannya, karena kekurangan penyuluh yang dimiliki. Tenaga BPP kurang: 3 orang, yang terdiri dari 1 koordinator/penyuluh dan 2 orang penyuluh. Ketiganya harus mengelola 5 desa untuk mewakilisemua urusan dinas pertanian di kecamatan ini.

Setiap minggu BPP Pleret harus melaporkan perkembangan pertanian dan peternakan ke Dinas Pertanian, selain mengisi data Kartu Tani dari semua kelompok tani di kelima desa di Kecamatan Pleret. Untuk pengisian data itu ia harus mengumpulkan data dari berbagai kelompok tani yang tidak semua memiliki data lengkap. Dengan demikian, beban pekerjaan seperti ini tidak memungkinkan ketiga orang ini mendampingi para petani secara intensif, selain tiadanya dukungan dana pendampingan, dan sebagainya, yang diperlukan para penyuluh dalam melakukan tugas.

Dalam merealisasikan percontohan itu BPP dan Kelompok Tani Perwira itu memerlukan mitra. Mas Sugeng Diono, salah sorang penyuluh, mengundang UAJY untuk berkenalan dan berdiskusi tentang hal ini. Beberapa kali kontak WA akhirnya berujung pada pertemuan di BPP Pleret beberapa kali. Tim UAJY mendengarkan apa yang menjadi aspirasi, permasalahan, keinginan dan cita-cita setiap peserta yang hadir. Pada akhir diskusi disepekati beberapa hal: cek lahan, sinergi rencana, rekapitulasi sumberdaya dan akses dukungan, pembuatan demplot, koordinasi rutin, memastikan keberhasilan demplot untuk program ekstensifikasi, adopsi teknologi budidaya, pemasaran produk dan peningkatan daya tarik agar petani datang untuk berlatih bersama, penekanan pada komoditas unggulan per desa. Namun untuk melakukan semua itu perlu langkah awal: pembuatan kebun pertanian organik (sehat) terpadu.

Kegiatan PPM UAJY ini adalah upaya untuk merealisasikan langkah pertama: pewujudan percontohan pertanian organik dengan adopsi “Teknologi Tetes Air”. Ada sejumlah permasalahan mitra yang akan dijawab dengan solusi yang diajukan oleh Tim PPM UAJY. Agar keberdayaan Taruna Tani tercapai, tim mengajukan metode terdiri dari beberapa langkah yang akan disangga oleh 4 shareholders: Tani Perwira, BPP Pleret, PPL Swadaya/Petani Pelopor, Tim PPM UAJY, sehingga terjadi sinergi dan kesinambungan dalam pelaksanaan kegiatan PPM ini. Tim PPM UAJY melakukan inisiasi inovasi budidaya, melakukan mediasi relasi eksternal dan fund raising dengan dana PPM dan dana desa Pleret. BPP berkontribusi dalam menyediakan lahan, pendampingan dan mediasi kerjasama. Petani milenial berkontribusi dalam mengelola lahan sampai panen dan meneruskannya sebagai pertanian berkelanjutan, sedangkan mahasiswa yang terlibat dapat menerapkan ilmu dan data yang diperoleh dari hasil riset MBKM sebelumnya. Dengan demikian pewujudan percontohan pertanian organik dengan adopsi "Teknologi Tetes Air" dapat membawa manfaat bagi para petani secara khusus dan masyarakat secara umum.

\section{Metode Pengabdian}

\section{A. Koordinasi Lapangan}

Koordinasi lapangan dilakukan dengan melibatkan Perwira Tani, BPP Pleret, dan mitra lapangan: peralatan dan tenaga penggarap olah lahan. Koordinasi didasarkan pada tatakala yang ada pada proposal pengabdian. Pengadaan traktor, pompa air, tandon air berjagrak besi, greenhouse, peralatan instalasi sistem tetes air, mulsa dll. akan disediakan oleh mitra dan toko. Tenaga penggarap lahan dimediasi oleh BPP Pleret dan petani milenial. Pembuatan pupuk organik cair dilakukan oleh Tim PPM UAJY, BPP Pleret dan petani milenial. Dokumentasi proses dan hasil disediakan oleh Tim PPM UAJY.

\section{B. Perancangan dan Pemasangan Peralatan}

Perancangan dilakukan untuk tandon air, greenhouse, lahan pertanian, sistem teknologi tetes, serta dokumentasi visual dan audiovisual. Pada tahap awal, perancangan posisi, ketinggian, kekuatan jagrak besi dan ukuran tandon air didiskusikan bersama. Setelah disepakati, tim lalu memesan ke mitra pengadaan. Pemasangan dilakukan setelah rancangan selesai dituangkan ke dalam wujud produk. Penempatan jagrak ada di sisi timur kantor BPP Pleret, di selatan greenhouse. Air akan "ditarik" dari sumur yang ada di belakang kantor BPP Pleret. Pemasangan berhasil dilakukan beberapa hari sebelum pemasangan greenhouse dimulai.

Greenhouse dirancang dengan ukuran yang disesuaikan dengan kebutuhan pembibitan. Bahan penopang dipilih yang cukup tebal agar tidak bergoyang karena tiupan angin. Bahan baja ringan dipilih agar lebih bisa bertahan lama, demikian 
pula kualitas atap dan penutup samping. Mitra penyedia memasangnya setelah siap. Tanggal 21 Desember 2021 greenhouse telah berhasil dipasang di halaman BPP Pleret.

Lahan penanaman diolah dengan traktor yang disediakan oleh Tim PPM UAJY. Rumput sengaja tidak dibersihkan tetapi langsung dilindas oleh traktor agar ia berada dan tercampur dengan tanah sehingga nanti menjadi humus. Tanah dibuat gundukan memanjang sebagai media tanam dan atasnya dipasangi mulsa agar rumput liar tidak tumbuh di dekat perakaran cabai yang ditanam. Dengan teknologi waktu garap lahan cukup 1 hari dengan sedikit tenaga kerja sehingga ekonomis.

Peralatan instalasi teknologi tetes telah datang sebagian ketika tim datang ke BPP Pleret pada 17 Desember 2021. Alat ini mulai dicicil pemasangannya dengan mulai memasang pipa paralon penguhubung antara tandon air dengan lahan bermulsa. Pemasangan lengkap dilakukan setelah olah lahan selesai. Pipa paralon dihubungkan dengan juluran selang air khusus yang kemudian secara keseluruhan bisa diatur volume dan frekuensi tetes airnya. Setelah seluruh instalasi siap maka ujicoba akan dilakukan. Petani milenial akan menjadi subyek utama pada kegiatan ini.

Peralatan dokumentasi telah disiapkan pada Kamis 16 Desember 2021 oleh Mas Wahyu. Dua kamera, dua mic, dua treepod, dan alat editing telah disiapkan. Pengambilan gambar dilakukan bukan hanya pada hasil, tetapi juga pada seluruh proses, dengan sisipan beberapa wawancara kepada penyuluh pertanian, petani milenial, Tim PPM UAJY dan mitra pengadaan peralatan dan tenaga garap lahan. Wawancara pertama telah dilakukan oleh anggota Tim PPM UAJY kepada Koordinator BPP Pleret pada Jumat 17 Desember 2021. Perancangan pengambilan gambar didiskusikan di Joy Angkring, barat Tugu Yogyakarta, dan BPP Pleret. Hasil dokumentasi adalah video dan unggahan pada youtube dan media sosial.

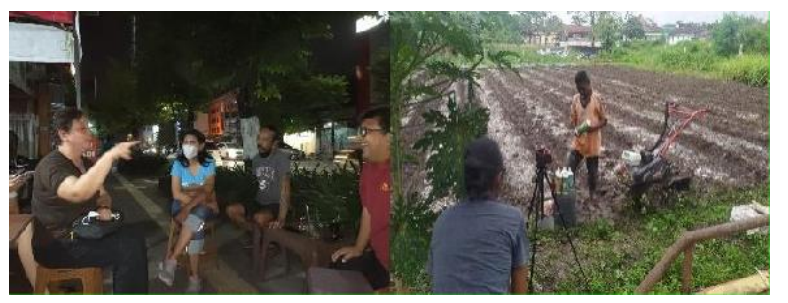

Gambar 1 Koordinasi Tim AV dan Pengambilan Gambar di Lahan

\section{Pelatihan dan Pendampingan Budidaya}

Budidaya akan diawali dengan palatihan pembuatan pupuk organik cair. Karena waktu mendesak, pembibitan dilakukan dengan pengadaan bibit jadi yang akan dirawat sebentar di dalam greenhouse sebelum ditanam di lahan. Dalam pelatihan akan disempaikan bukan hanya mengenai budidaya organik, tetapi juga mengenai filosofi organis dan pengorganisasian kelompok. BPP dan Tim PPM UAJY akan bekerjasama dalam hal ini. Tani Perwira akan menjadi subyek utama dalam tahap ini karena merekalah yang menjadi pelaku utama dalam budidaya cabai di luar musim. Pendampingan dilakukan secara bersama pasca pelatihan sampai dengan panen, bahkan penanganan hasil panen dan pemasarannya. Pemantauan dan evaluasi berkala dilakukan untuk memastikan capaian program. Tingkat partisipasi petani milenial, kemampuan mereka mengoperasikan sistem teknologi tetes, kualitas perawatan dan budidaya di lahan, kualitas panen, dan hasil pemasaran, di samping pemahaman mendalam mengenai penerapan filosofi organis serta keberlanjutan budidaya ke depan, akan menjadi parameter keberhasilan program ini.

\section{HASIL DAN PEMBAhaAN}

\section{A. Upaya Penumbuhan Petani Muda/Milenial}

Usia petani sekarang banyak yang sudah tua dan kurang dapat menyerap teknologi baru. Teknologi yang baru akan menghemat tenaga, misalnya alat panen padi, alat tanam bibit padi, penggunaan traktor, drone untuk pemupukan, dan dripping water system akan menghemat air, pupuk, insektisida dan fungisida. Jenis teknologi tidak dapat dimanfaatkan usia petani di atas 40 tahun. Untuk dapat menyerap transfer teknologi pilihannya adalah petani milenial karena masih dapat berkembang dan cepat menyerap informasi serta teknologi. Dengan demikian, pelaksanaan tata kelola pertanian bisa menjadi maju, stok barang tersedia dan tidak menimbulkan gejolak nasional.

Mahasiswa termasuk di dalam kelompok milenial yang diharapkan dapat menjadi penyambung informasi: dari kampus ke komunitas petani. Mahasiswa yang "terjun" ke sawah akan memiliki daya tarik tersendiri selama mereka menekuni pertanian. Pemahaman bahwa bekerja sebagai petani itu melelahkan karena berlangsung sepanjang hari adalah kelitru, karena sekarang sudah banyak peralatan yang dapat mengefisienkan tenaga petani. Melalui program Merdeka Belajar dan Kampus Merdeka (MBKM), mahasiswa terdorong untuk "terjun" ke masyarakat agar dapat lebih berkarya di dunia nyata kehidupan, termasuk sektor pertanian

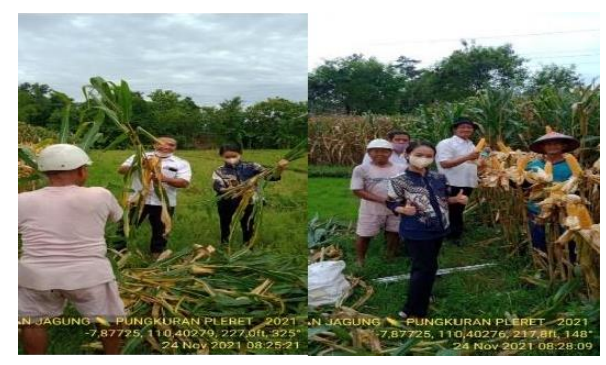

Gambar 2 Dea, Mahasiswa MBKM FH UAJY

Salah seorang mahasiswa yang tertarik mengikuti program MBKM di sektor pertanian adalah Benedita Dea Puspita. Mahasiswa Fakultas Hukum Universitas Atma Jaya Yogyakarta ini mendaftarkan diri sebagai mahasaiswa program MBKM di fakultasnya dengan memilih sector pertanian karena kelak ingin bekerja di birokrasi pemerintahan bidang pertanian pula. Oleh karena itu, ia mempersiapkan diri dengan mengikuti program ini. BPP Pleret yang menjadi mitra Pusat Studi HAM dan Demokrasi Universitas Atma Jaya Yogyakarta pun bersedia menerimanya untuk menggunakan BPP Pleret sebagai subyek penelitiannya. Oleh karena itu, ia pun memilih topik 
yang relevan dengan fakultas hukum tetapi juga tetap mempelajari sektor pertanian. Dengan berbagai pertimbangan dan diskusi, ia akhirnya memilih untuk meneliti kebijakan pendanaan pemerintah terhadap BPP sebagaimana di atur oleh undang-undang.

Ia mencari aturan perundangan yang mengatur sektor pertanian ini. Pada aturan itu kemudian ia mencari pasal-pasal yang mengatur apa saja didanai oleh pemerintah dalam operasionalisasi sebuah kantor BPP, berikut para penguluh pertaniannya. Ia kemudian menemukan beberapa pasal yang mengatur hal ini.

Aktivitasnya di BPP Pleret itu kemudian membawa PSHD UAJY bekerjasama dengan Kelompok Tani Perwira ketika ada tawaran untuk melakukan pengabdian pada masyarakat dari Direktorat Jenderal Pendidikan Tinggi, Riset dan Teknologi. Dengan disetujuinya proposal yang diajukan maka tim pengabdian PSHD UAJY dapat melakukan aktivitas konkret di wilayah kerja BPP Pleret ini, yaitu area di mana Kelompok Tani Perwisa berada [4] [5] [6].

Dengan demikian, keberadaan mahasiswa MBKM memberi peluang universitas untuk bekerjasama dengan pelaku pertanian. Pengabdian ini adalah outcome dari keberadaan Dea melakukan penelitian mandiri sebagai salah satu dari delapan kegiatan di dalam program MBKM,

Dari pembicaraan dengan Koordinator BPP Pleret, Pak Karno, yang menjadi pendamping kelompok tani milenial itu, yaitu Tani Perwira, maka jatuhlah gagasan pada budidaya tanaman cabai di luar musim dengan menggunakan sistem tetes. Mengapa cabai di luar musim yang dipilih sebagai tanaman pertanian? Menurut Pak Karno, hal itu merupakan upaya untuk mendorong para petani milenial untuk mau terjun ke dunia pertanian. Kalau mereka diajak untuk bertani di persawahan padi maka besar kemungkinan mereka tidak akan sanggup karena becek, "kotor" dan "berat" sehingga hasrat untuk bertani dapat susut kembal. Bertani padi pun secara ekonomi tidak menguntungkan karena ada harga patokan yang ditetapkan oleh pemerintah ketika beras dipasarkan. Hal ini berbeda dari cabai yang harganya memiliki fluktuasi rentang harga relatif lebar: 8.000-100.000 rupiah. Ada harapan untuk memperoleh keuntungan besar ketika panen nanti, apalagi bila menanamnya di luar musim, seperti usulan Pak Karno ini. Dengan pilihan ini, sebagai pendamping Kelompok Tani Perwira, Pak Karno mengusulkan budidaya pertanian cabai sebagai pilihan pengabdian bagi tim pengabdian dari UAJY ini.

Mengapa sistem tetes yang dipilih? Hal ini belajar dari apa yang dilakukan oleh petani muda di berbagai tempat bahwa teknologi menjadi pilihan untuk efisiensi perawatan, peningkatan hasil, dan memudahkan dalam bekerja. Mas Heri Santoso di Sukoharjo menggunakan aliran air sesuai dengan kemiringan tanah dan tandon air besar berisi ikan yang diternak berhasil menghasilkan aneka produk sayuran, padi, ayam dan ikan di lahan yang sama seluas 2 hektar dengan 2 orang pekerja yang mengoperasikannya. Kedua tenaga kerja ini tinggal mengatur keran air ketika hendak mengairi sawah dan sayuran. Petani muda lain menggunakan sistem teknologi tetes yang ia pesan dari Israel untuk menanam cabai dan lainlain di lahan hortikulturanya di salah satu kabupaten di Propinsi Nusa Tenggara Timur (NTT).
Apakah tidak mahal pengadaan teknologi pertanian? Jawaban ini menjadi relatif. Bagi kedua petani milenial di atas, di Jawa Tengah dan NTT, pengadaan teknologi yang cukup mahal di awal usaha akan menghemat pengeluarannya pada rentang tahun mendatang sehingga secara ekonomi tetap menguntungkan. Dengan teknologi ini mereka menghemat tenaga kerja, memudahkan dalam merawat tanaman, memberikan kepastian aliran air ketika lahan tidak memiliki pasokan pengairan yang pasti karena merupakan daerah yang tergolong kering, dan penghematan waktu ketika merawat memungkinkannya untuk mengerjakan hal lain. Dengan demikian sektor pertanian tidak menghabiskan waktunya sepanjang hari dalam beberapa bulan masa tanam dan rawat (budidaya) sampai panen tiba.

Hal inilah yang tidak dapat dengan mudah diserap oleh petani tua. Menurut Pak Karno dan para penyuluh di BPP Pleret, usia petani di kawasan ini di atas 40 tahun. Untuk wilayah Pleret yang relatif dekat dengan Kota Yogyakarta, proses pengkotaan membuat aneka pekerjaan sektor nonpertanian tersedia cukup luas. Oleh karena itu banyak generasi muda tertarik untuk bekerja di sektor ini karena memberikan pendapatan ekonomi lebih pasti. Mereka menjadi pekerja harian, mingguan atau bulanan di berbagai sektor jasa, perdagangan, konstruksi dan lain sebagainya. Mereka tidak terancam oleh hama penyakit yang membuat mereka kehilangan potensi keuntungan, seperti yang dialami oleh para petani. Mereka juga mengetahui bahwa sektor pertanian rentan terhadap perubahan kebijakan pemerintah, misalnya impor beras, kenaikan harga pupuk, harga eceran tertinggi (HET), kartu tani, dan sebagainya, yang membuat petani harus menyesuaikan diri. Hasil pertanian padi, misalnya, hanya dapat mencukupi kebutuhan pangan pokok tetapi belum dapat mencukupi kebutuhan lauk-pauk, pendidikan anak, listrik dan dana sosial (kelumrahan). Oleh karena itu, sektor pertanian tidak menarik minat mereka karena tidak akan dapat mencukupi kebutuhan keluarga, rentan gagal panen dan mudah "tergoncang" oleh perubahan kebijakan pemerintah.

Namun di sisi lain, bila petani muda tidak ada lagi, siapakah yang akan menggarap sekian luas areal pertanian di Kecamatan Pleret? Siapakah yang menyediakan pasokan pangan kita nanti? Apakah kita akan mengandalkan impor dari negara lain bila "hilangnya petani" terjadi di berbagai wilayah Indonesia secara merata? Hal inilah yang menjadi pertimbangan BPP Pleret untuk berjuang menghidupkan hasrat generasi muda akan sektor pertanian. Para penyuluh yang berpengalaman tahu bagaimana transisi harus dilakukan agar generasi muda tertarik mengerjakan sektor ini. Maka tanaman hortikultura (termasuk cabai) dan teknologi menjadi pilihannya. Mereka berharap dengan pilihan ini minat kaum milenial ke sektor pertanian akan meningkat sehingga regenerasi petani tetap dapat terjaga.

Oleh karena BPP memiliki tugas untuk melatih para petani maka sumbangan tim pengahdian UAJY ini memberikan peluang BPP Pleret untuk melatih Tani Perwira secara memadai. Kelompok Tani Perwira menjadi penerima manfaat (grantee) pada kegiatan pengabdian yang didanai oleh Ditjen Diktiristek ini. Keberadaan peralatan sistem tetes ini akan memudahkan mereka dalam melakukan budidaya, demikian greenhouse untuk persemaian (agar tidak rusakoleh hama dan hujan deras). Mereka diharapkan kian tumbuh 
semangatnya sebagai petani dan pelatihan kian intens dilakukan melalui pengerjaan di lahan dan pendampingan intensif oleh para penyuluh pertanian dan petani milenial yang lebih maju pengetahuan dan keterampilannya dalam berbudidaya. Lahan dan teknologi sederhana ini diharapkan dapat menjadi percontohan bagi budidaya pertanian organik untuk tanaman hortikultura.

Semua kegiatan ini, bagi Tim Pengabdian UAJY, dilakukan untuk mewujudkan percontohan Pengabdian pada Masyarakat (PPM) pertanian organik dengan adopsi "Teknologi Tetes Air". BPP Pleret dan Kelompok Taruna Tani "Tani Perwira" bekerjasama sebagai pelaku percontohan di lapangan.

\section{B. Pelaksanaan Kefiatan PPM}

\section{Pembuatan Menara Air}

Menara air dibangun untuk mengankat bak air dengan volume 650 liter. Bak air ini digunakan untuk menyimpan air sebelum diedarkan ke tanaman cabai melalui teknologi tetes air. Teknologi tetes air akan mengatur kebutuhan air, pupuk organik dan obat tertentu untuk setiap tanaman cabai. Bak air, selain untuk menyirami, juga digunakan untuk memberi pupuk organik cair dan pestisida organik yang dilarutkan ke dalam bak, sehingga bisa didarkan secara merata dan berkesinambungan melalui tetes air.

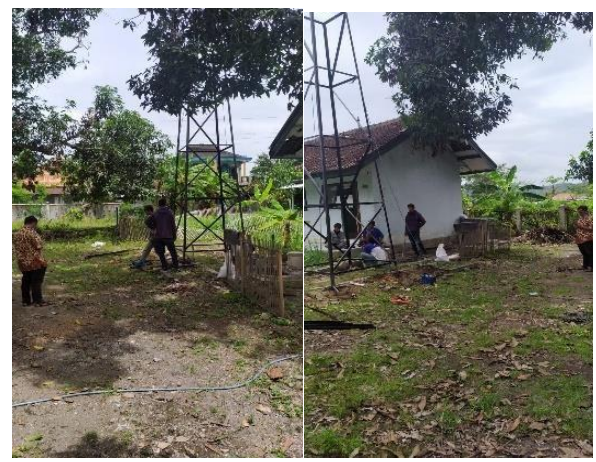

Gambar 2 Pemasangan Tandin Air

\section{Pembuatan Greenhouse}

Pembuatan greenhouse digunakan untuk menyediakan tempat bagi persemaian bibit tanaman cabai.Bibit tanaman cabai yang telah banyak daun boleh "dilepas" dulu dari greenhouse untuk ditaman di bedengan tanah bermulsa. Bibit yang belum siap tanam tetap disemai dan diamati pertumbuhannya di dalam greenhouse yang diberi kasa aluminium ini.

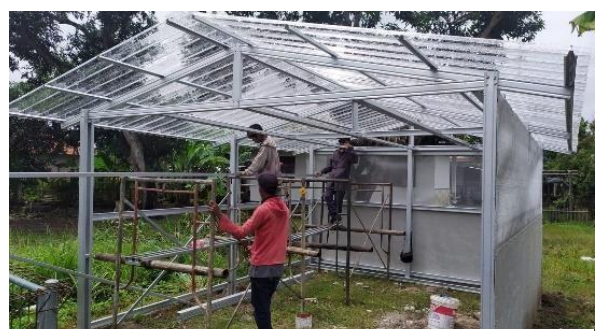

Gambar 3 Pemasangan Greenhouse
Kasa aluminium mengamankan bibit dari ancaman hama penyakit ketika pertumbuhannya masih dini. Bibit tanaman akan lebih terlindungi dari ancaman hama penyakit dan iklim bila dirawat di dalam greenhouse.

\section{Pembelian Cultivator Quick Cakar Baja}

Alat ini diperlukan untuk pengolahan lahansebelum penanaman bibit cabai dilakukan. Mengingat kawasan Pleret sudah susah mencari tanaga kerja sektor pertanian (buruh tani) maka peralatan mekanik menjadi pilihannya. Mekanisasi pertanian memang diperlukan ketika tenaga kerja manual tidak memungkinkannya lagi, selain alasan efektivitas dan efisiensi.
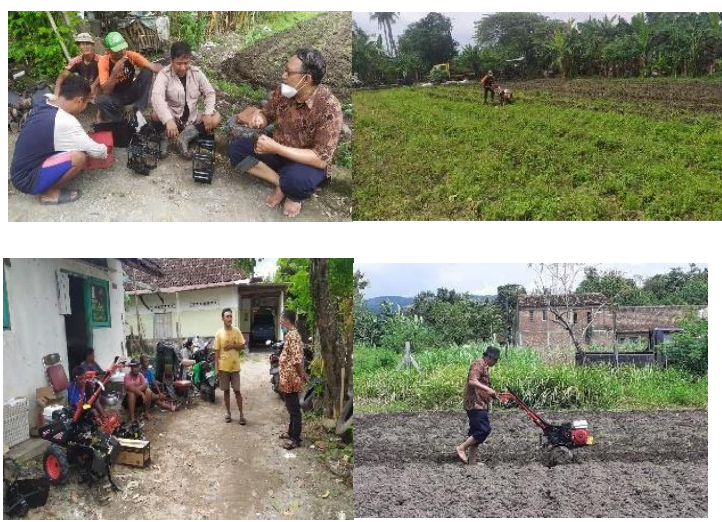

Gambar 5 Perakitan alat dan penggunaan olah lahan

Tentu saja adaptasi teknologi diperlukan dalam hal ini. Taruna tani harus mempelajari cara kerja mesin, mengetahui cara merawat, mengetahui cara penggunaan, dan mengetahui manfaatnya. Mereka juga belajar dalam menyisihkan anggaran untuk BBM operasionalisasi peralatan mekanik ini,di samping dana perawatan bila ada kerusakan dan penggantian suku cadang karena semuanya ada batas usianya.

Oleh karena itu, kesadaran, kerjasama dan manajemen kelompok menjadi penting dilakukan di balik penggunaan peralatan mekanik ini. Iuran anggota, pembagian tugas dan pengecekan mesin menjadi hal yang semula tidak mereka lakukan ternyata kini harus mereka hadapi.

Tentu saja ada perasaan gembira ketika Kelompok Tani Perwira menerima bantuan ini. Namun bantuan ini memerlukan tanggung-jawab besar sebagai konsekwensinya. Banyak bantuan teknologi dari pemeritah dan swasta mangkrak karena komitmen perawatan dan tanggung-jawab bersama melemah kemudian hilang. Oleh karena itu, bantuan peralatan ini adalah amanat uang rakyat yang harus dikelola agar manfaatnya sungguh bisa menggugah generasi milenial untuk mau bertani karena teknologi memudahka mereka dalam bekerja di lahan pertanian.

Peralatan ini juga bisa menghasilkan pendapatan ketika disewa atau menjadi alat untuk 
menggarap lahan lain. Bila kelompok tidak menggunakan maka alat bisa disewakan atau dipakai oleh anggota kelompok mengerjakan lahan lain yang diminta oleh kadang tani lain. Pendapatan dapat Sebagian dimasukkan ke dalam kas bersama. Pendapatan lain dimiliki oleh anggota kelompokyang mau mengerjakannya. Tabungan kas ini dapatdipakai untuk biaya perawatan alat bila terjadi kerusakan atau servis agar tetap terjaga“"kesehatan"nya.

\section{Pembibitan Cabai}

Cabai sejak lama dikenal sebagai bumbu yang memberikan rasa pedas pada aneka masakan. Secara umum cabai dapat dibedakan menjadi dua kelompok besar, yaitu cabai besar dan cabai kecil (rawit). Cabai yang dikenal di Indonesia diantaranya spesies Capsicum annum (cabai besar), Capsicum frutescents (cabai kecil) dan Capsicum Chinense[4]

Saat ini hampir semua negara di Kawasan Asia berlomba-lomba untuk mengekspor komoditas cabai dengan harga bersaing. Hal ini tentu merupakan suatu tantangan sekaligus dorongan bagi dunia percabaian di Indonesia. Dengan pesatnya perkembangan industri makanan,minuman, farmasi, dan sejenisnya yang menggunakan cabai sebagai bahan bakunya, bukan hal yang tidak mungkin bila ekspor cabai Indonesia lebih ditingkatkan kembali. Segalanya tentu masih terbuka sejauh mutu cabai Indonesia ditingkatkan.

Jika ditelusuri dari asul-usulnya, dapat dinyatakan bahwa cabai lebih cocok ditanam di daerah tropis yang secara langsung dilalui oleh garis khatulistiwa. Tanaman cabai cenderung mudah beradaptasi terhadap daerah tumbuh yang baru sehingga penyebarluasnya mampu melintasi berbagai iklim. Varisi musim ini adalah dua musim (kemarau dan hujan) di daerah subtropis dan empat musim (dingin, semi, panas, gugur) di daerah beriklim sedang. Di daerah tropis, tanaman cabai dibudidayakan tidak hanya di area tegalan, melainkan di persawahan, baik di dataran rendah maupun tinggi, dengan waktu penanaman dapat dilakukan pada musim kemarau maupun penghujan. Meskipun demikian, tanaman cabai memerlukan persyaratan tertentu agar bisa memberikan hasil terbaik.

Sebelum cabai ditanam, benih atau biji perlu disemai terlebih dahulu. Penyemaian atau pembenihan ini bisa dilakukan di polybag maupun tray. Hal yang penting untuk dilakukan dalam proses penyemaian benih cabai adalah: a) sebelum benih ditanam perlu dilakukan penyeleksian benih, b) selama persemaian, benih atau calon bibit dirawat dengan sungguhsungguh sehingga menjadi bibityang baik, dan c) tempat persemaian harus dijaga kesuburannya.
Tempat pembenihan sebaiknya dilakukan di dalam greenhouse agar benih terlindung dari berbagai ancaman dan memudahkan merawat ketikamusim penghujan. Bibit disemai dalam polybag/tray yang telah diisi dengan media tanam yang terdiri dari pupuk organik sebanyak $50 \mathrm{~g}$ per polybag, tanah dan sekam arang. Komposisi media dapat mengacu pada aneka hasil percobaan sesuai dengan jenis tanaman yang akan disemai.

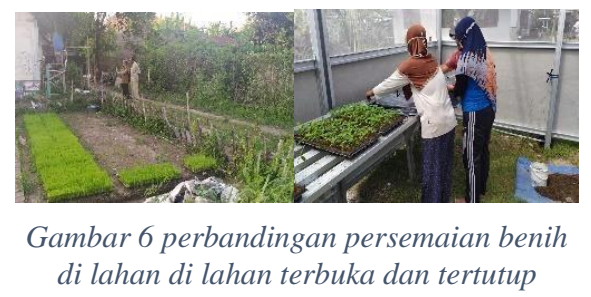

Sebelum disemai, benih cabai harus diseleksi terlebih dahulu. Benih harus dipilih yang berkualitas berdasarkan ukuran benih yang dipasarkan perusahaan penghasil benih, yaitu itu sebagai berikut.

a) Daya tumbuh tinggi minimal $85 \%$ dan 6-12 hari setelah semai.

b) Tingkat keseragamannya tinggi berdasarkan kemurnian varietas benih, bentuk, warna dan ukuran.

c) Tingkat kadar air untuk disimpan lama berkisar 7-8\%, dengan kondisi ini benih dapat disimpan sampai 5 tahun.

d) Benih bebas Organisme Pengaanggu Tanaman (OPT) dan penyakit.

e) Ciri fisik baik, yaitu kulit biji/benih mengkilat, tidak berjamur tidak kisut dan tidak rusak bekas dimakan hama.

4. Pemasangan Instalasi Sistem Tetes
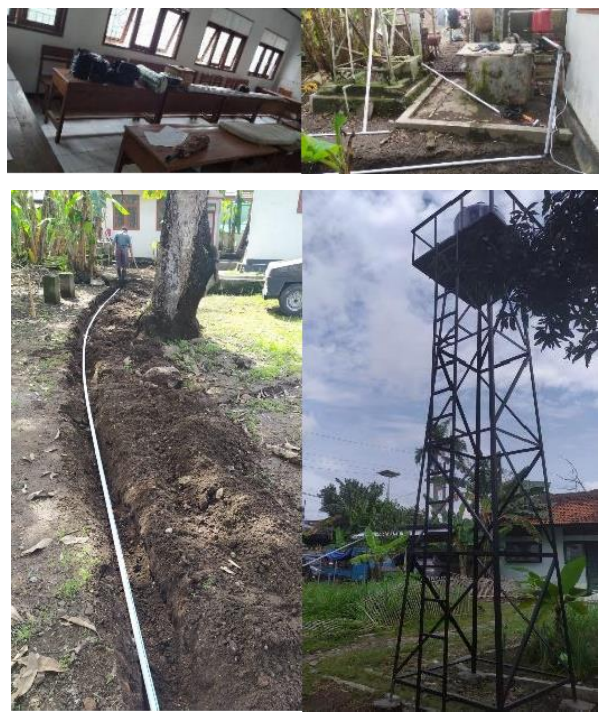


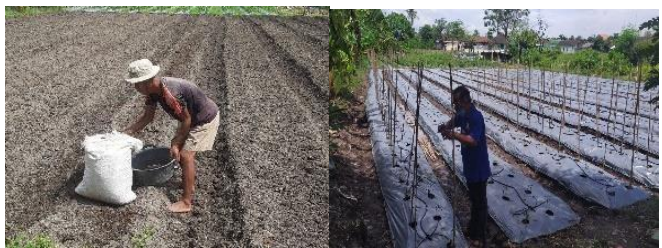

Gambar 7 Tower tandon air, peralon dari sumur, peralatan sistem tetes air, olahan lahan, penyambungan instalasi sampai ke lahan bududaya cabai

Sebelum bibit ditanam di lahan maka instalasi sistem tetes air harus disambungkan dan diuji-coba. Penyambungan paralon penghubung aliran air dari sumur, ke tampungan air di atas tower, dialirkan turun melalui pipa dan saluran tetes menuju tanaman di lahan bedengan tanah bermulsa yang telah ditanam cabai yang telah siap tanam. Lanjaran atau ajir di siapkan pada setiap lobang mulsa. Pada setiap lobang mulsa telah ditanam bibit yang telah siap tanam. Terhadap bibit di lahan inilah aliran air akan menetes pada perakaran tanaman.Ajir atau lanjaran digunakan untuk mendampingi pertumbuhan tanaman bila batang belum cukup kuat. Berapa tetes air per menit diberikan kepada tanaman cabai di lahan akan disesuaikan dengan kebutuhannya. Karena berbeda daripadi yang memerlukan air tergenang pada tahap vegetatif tertentu, tanaman cabai tidak demikian. Ia memerlukan air selalu membasahi akarnya sampai akar kuat dan mandiri mencari makanan di lahan tanah di mana ia ditanam. Oleh karena itu, pengolahan tanah menjadi penting untuk dilakukan.Olah tanah yang benar sehingga unsur hara tersedia dengan bantuan pemupukan dengan pupuk organik cair (POC) sangat membantu perakaran dalam mencari unsur hara untuk menumbuh-kembangkan tananamn.

Organ tanaman cabai akan membesar sesuai dengan ketersediaan kesuburan tanah yang mengandung aneka unsurmakro (N. P, K, Ca) dan mikro ( $\mathrm{Mg}, \mathrm{Fe}, \mathrm{K}, \mathrm{Ph}$, dll.). Kebutuhan tanaman akan kesemua unsur kesuburan inilah yang harus diamati dan dipelajari. Dunia pertanian adalah dunia yang rumit karena lahan berjejeran bisa jadi kesuburannya berbeda karena kandungan unsur hara di setiap jengkal lahan berbeda. Oleh karena itu tidak ada rumus baku yang pasti tepat dalam pemupukan dan perawatan karena variasi kesuburan tanah sangat variatif. Amatan lahanlah yang menentukan. Itulah sebabnya petani harus rajin mengamati proses pertumbuhan tanaman di lahan [5] [6] [7].

\section{Budidaya Organik}

Setelah tubuh tanaman tumbuh bagus, petani perlu mencermati pertumbuhan buah. Bisa jadi tanaman subur tetapi bunga dan buah yang dihasilkan bermasalah karena berbagai faktor. Oleh karena itu, adalah benar bila ada yang mengibaratkan menanam bibit tanaman hingga berbuah seperti “merawat bayi". Ia tidak hanya butuh makanan, tetapi juga perhatian. Sebab itu, Mas Suryono, salah seorang petani di kelompok Tani Perwira, mengatakan bahwa ia mengajak bicara tanamannya. Semakin sering dikunjungi, diperhatikan dan diajak bicara maka semakin baguslah pertumbuhan dan hasil yang diberikan tanaman itu. Seperti kita, tanaman adalahmakhluk hidup yang juga memerlukan perhatian. Ia memiliki "perasaan" dan "energi" yang pancarannya dapat ditangkap oleh petani "berhati" seperti Mas Suryono tersebut.

Hal ini persis seperti filosofi "organis" yang disampaikan oleh Mas Daryanto dan Mas Wangsit sebagai aktiivis pertanian organik. Mengikuti filosofi Romo Agatho di Megamendung, budidaya organik memerlukan penghayatan organis. Organis berkata dasar "organ", yang berarti "bagian". Dalam semesta raya ini, kita adalah organ yang sangat kecil, sebagaimana sel-sel di dalam tubuh kita. Apa yang terjadi pada satu organ akan berpengaruh pada organ yang lain. Oleh karena itu, kita harus menjadi organ yang baik, yang berkoeksistensi terhadap kabaikan organ-organ yang lain. Baik dan buruk dalam kehidupan memiliki fungsinya masing-masing. Gelap menjadi pembeda dan pengetahuan bagi kita agar tahu adanya terang. Hama penyakit mendorong kita belajar untuk mengetahui sebabnya dan mengatasinya dengancara nir-kekerasan karena setiap organ memang memiliki fungsi positif dan negatifnya sendirisendiri. Oleh sebab itu, berbudidaya organik adalah budidaya nir-kekerasan, budidaya yang mau "berbagi" terhadap keberadaan makhluk hidup yang lain, entah itu serangga, burung, atau yang lain.

Agar manusia tetap memperoleh hasil tanam maka ia perlu menghalau hama penyakit dengan mencarikan penangkal atau musuh alaminya. Manusia perlu tahu keanekaragaman hayati di sekitarnya. Oleh karena itu, budidaya organik memerlukan pemahaan multi-kultur, keragaman hayati, bukan monokulturdan aneka pupuk dan pestisida kimiawi sintetis yang dapat merusak makhluk hidup lain baik di atas maupun di dalam tanah yang merupakan bagaian dari mata-rantai makanan di dalam ekosistem kehidupan kita.

Tentu saja maksimalisasi hasil tidak akan sama dengan pertanian konvensional yang berkimia-sintetis. Pertanian organik adalah pertanian "berbagi" sehingga ia rela bila Sebagian hasilnya dimakan makhluk hidup lain karena semua "organ kehidupan" memerlukan kehidupan pula. Koeksistensi antarorgan kehidupan. Oleh karena itu, sikap nir-kekerasan diperlukan sebagai bagian interal pada diri pelaku.

Koeksistensi ini bukan hanya pada ranah real, konkret dan kasat-mata, melainkan juga nir-kasar-mata. Ada penghayatan bahwa pada setiap kehidupan hadirlah Sang Hidup. Pancaran "energi" Sang Hidup inilah yang berada pada semua tanaman, serangga, renik dalam tanah, cacing, belalang, dan sebagainya, yang pada dirinya memiliki hak hidupnya. Manusia bukanlahTuhan, maka kalau Tuhan saja memberi mereka kesempatan hidup maka kenapa kita memusnahkannya dengan aneka produk kimia-sintetik? Oleh karena itu, pengetahuan ekologis diperlukan agar kita bisa menghalau mereka, berbagi secara proporsional, dan berdoa untuk tumbuhnya tanaman dab bahkan menghalau tanaman. 
Hal terakhir ini seperti pengalaman Cak Wahab di Jombang yang menghalau tikus dengan ritual tertentu dan berhasil,

Oleh karena itu, bertani adalah berdoa dan berbagi. Itulah sebabnya dalam tradisi Jawa ada slametan ketika upacara wiwit dilakukan. Wiwit bermakna kesinambungan karena ketika panen kita mengambil benih baik untuk dijadikan benih tanaman pada musim depan, Maka benih pilihan itu adalah "wiwitan", awal, bagi budidaya pada musim tanam berikutnya. Pada titik inilah kita mengenal pertanian berkelanjutan yang berbasis pada pengetahuan dan keahlian berbudidaya organik, sikap organis dan dan relasi transcendental-adikodrati. Maka budidaya organik adalah pemuliaan kehidupan, bukan hanya untuk pemenuhan kebutuhan fisik-biologis dan ekonomis saja.

Tanaman cabai di lahan perlu untuk dibudidayakan dengan pamahaman di atas bila ingin melakukannya sungguhsungguh organis, bukan hanya sebatas dengan menggunakan pupuk organik cair dan pestisida hayati semata. Sikap organis jauh lebih mendalam daripada budidaya organik [8].

\section{Serah Terima Bantuan}

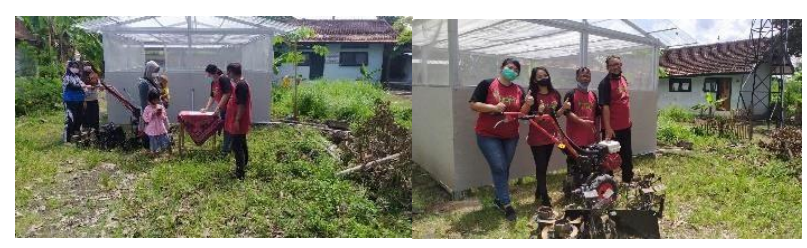

Gambar 8. Serah terima bantuan hasil PPM kepada Koordinator kelompok Tani Perwira

Setelah semuanya selesai dipersiapkan, ujicoba sistem tetes berhasil berjalan sebagaimana harusnya, tanaman telah siap di lahan dan greenhouse, peralatan mekanik telah dibersihkan, maka serah-terima dilakukan oleh Ketua Tim PPM: A. Wibowo Nugroho Jati. Para anggota tim, termasuk mahasiswa MBKM, menyaksikannya, demikian pula para anggota Kelompok Tani Perwira dan para penyuluh pertanian lapangan (PPL) BPP Pleret sebagai pendamping kelompok tanu milenial tersebut.

Meskipun penyerahan kepada Tani Perwira namun pengelolaan dan perawatan peralatan dilakukan bekerjasama dengan BPP Pleret. Hal ini sebagai langkah antisipatif bila ada hal yang tidak diinginkan, misalnya kelompok tani milenial ini bubar karena sesuatu hal. Dengan demikian peralatan yang mahal ini masih bisa diselematkan untuk dapat dipergunakan oleh petani milenial yang lain.

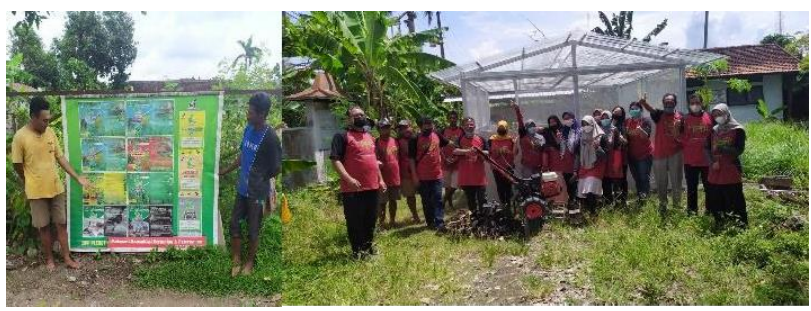

Gambar 9 Merayakan bersama keberhasilan program
Meskipun program ini telah selesai, tetapi program lanjutan menunggu: pendampingan. Oleh karena itu para pihak bersiap untuk mesuk ke dalam kerjasama lanjutan. Banyak bantuan dan pelatihan tidak berdampak positif bagi kemajan dan berhenti "di tengah jalan". Oleh karena itu kerja bersama diperlukan sekali dalam pendampingan para petani milenial.

\section{KESIMPULAN}

Permasalahan susutnya minat generasi muda mulai terjawab oleh program ini. Koordinator BPP Pleret menyatakan bahwa banyak pemuda desa yang menyatakan tertarik untuk berlatih pertanian dengan menggunakan sistem tetes ini. Antusiasme para taruna tani pun terasa ketika proses berlangsung dan serah-terima peralatan dilakukan. Para penyuluh pertanian menyatakan kegemniraannya atas hal ini sehingga semangat baru dalam pendampingan petani ke depan terasakan. Menurut Koordinator BPP, Lurah Desa Pleret pun berterima kasih dan antusias untuk mendukung program pertanian bagi generasi milenial ini dengan menggunakan dana desa. Pemerintah desa bahkan berniat untuk mengundang tim berdiskusi mengenai apa yang akan dilakukan ke depan untuk memajukan pertanian di Pleret.

Dengan demikian, cara mamandang pengeluaran peralatan yang cukup besar ini tidak dengan berapa panen cabai mendatang, tetapi hal itu dikaitkan dengan potensi penumbukembangan petani milenial di masa datang sehingga pertanian bisa berkalanjutan dan ketahanan pangan di Pleret dapat diberi kontribusi dengan kehadiran para petani milenial itu. Oleh karena itu, kerjasama pendampingan diperlukan kelanjutannya untuk mengawal cita-cita dan harapan bersama ini.

\section{UCAPAN TERIMAKASIH}

Ucapan terima kasih diberikan kepada Direktorat Jenderal Pendidikan Tinggi, Riset dan Teknologi yang telah memberikan Bantuan Pendanaan Program Pengabdian kepada Masyarakat Berbasis Hasil Penelitian dan Purwarupa PTS untuk membiayai kegiatan pengabdian ini.

\section{DAFTAR PUSTAKA}

[1] S. Nindito and B. K. Prihandono, "Pola dan strategi gerakan sosial lingkungan hidup dan pelestaruan sumber daya," Program Studi Sosiologi, Fakultas Ilmu Sosial dan Ilmu Politik, Universitas Atma Jaya Yogykarta, Yogyakarta, 2007.

[2] S. Nindito and K. Tamtomo, "Peninjauan Kembali Sejarah Dan Perkembangan Tiga kelompok Perintis Gerakan Sosial Pertanian Organik di Yogyakarta," Universitas Atma Jaya Yogyakarta, Yogyakarta, 2018.

[3] Wikipedia, "Profil Kecamatan Pleret," 2020. [Online]. Available:

https://id.wikipedia.org/wiki/Pleret,_Bantul. [Accessed 25 Oktober 2020]. 
[4] S. A. Pramono, "Daulat Benih Daluat Petani," AOI dan BfWD, Bogor, 2020.

Foto ke-n

[5] S. A. Pramono, "Geliat Petani dalam Himpitan korporasi dan Regulasi Dalam: Petani Buntung di Negeri Sawit," IPD, Yogyakarta, 2019.

[6] S. A. Pramono, Sepotong Kisah Desa Sepotong: Refleksi Jepitan Piramida Birokrasi dan Korporasi terhadap Desa Dalam: Desa Kuat Negara Berdaulat, Yogyakarta: IPD, 2019.

[7] Setiadi, Panen Padi Setiap Hari di Lahan Sempit, Jakarta: Penebar Swadaya, 2021.

[8] W. N. Jati, Pemanfaatan Isolat Bakteri Bacillus Thuringensis tehadap Hama Ulat Grayak (Spodoptera Litura) pada Tanaman kubis, Yogyakarta: Universitas Atma Jaya Yogyakarta, 2016.

[9] W. N. Jati, Pembuatan Pupuk Organik Cair, Yogyakarta: Universtas Atma Jaya Yogyakarta, 2015.

[10] W. N. Jati, A. S. Pramono and J. Widijantoro, "PKM Kelompok Petani Organik di Desa Sendangsari Kecamatan Pajangan, Kabupaten Bantul," in Seminar Nasional Hasil Pengabdian Pada Masyarakat, Yogyakarta, 2020.

[11] S. Nindito, "Revisiting Social Movement in Organic Agriculture Community in Yogyakarta, Indonesia," Advances in Social Science Education and Humanities Research, vol. 452, 2020.

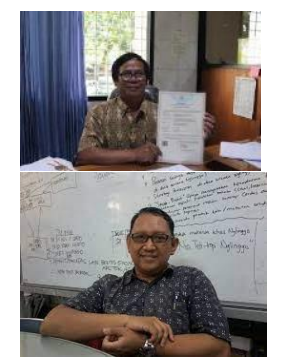

\section{PENULIS}

Drs. A Wibowo N Jati, MS, prodi Biologi, Fakultas Teknobiologi, Universitas Atma Jaya Yogyakarta.

Stefanus Nindito,S.Sos., M.Si, prodi Sosiologi, Fakultas Ilmu Sosial dan Ilmu Politik, Universitas Atma Jaya Yogyakarta.

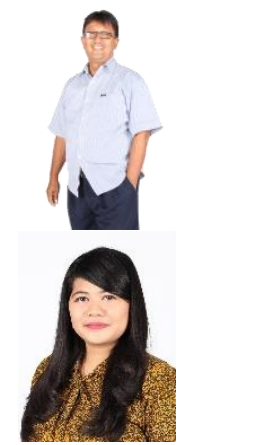

Surya Adi Pramana, SIP, M.Si, prodi Sosiologi, Fakultas Ilmu Sosial dan Ilmu Politik, Universitas Atma Jaya Yogyakarta.

Yustina Niken Sharaningtyas, prodi Ilmu Hukum, Fakultas Hukum, Universitas Atma Jaya Yogyakarta.

Benedeta Dea Puspita, mahasiswa prodi Ilmu Hukum, Fakultas Hukum, Universitas Atma Jata Yogyakarta
Nama Penulis ke n, prodi Informatika, Fakultas Teknologi Industri, Universitas Atma Jaya Yogyakarta. 